\title{
Development of an in vitro Caco-2 cell model system to measure iron availability from foods and meals
}

\author{
B. A. V. Thompson ${ }^{1}$, S. Al Mutairi ${ }^{1}$, P. A. Sharp ${ }^{2}$, R. M. Elliott ${ }^{3}$ and S. J. Fairweather-Tait ${ }^{1}$ \\ ${ }^{1}$ University of East Anglia, Norwich NR4 7TJ, Norfolk, UK, ${ }^{2}$ King's College, London SE1 9NH, UK and ${ }^{3}$ Institute of Food \\ Research, Norwich NR4 7UA, Norfolk, UK
}

An in vitro Caco-2-simulated digestion intestinal cell model has been developed to assess Fe availability by measuring ferritin formation in Caco-2 cells exposed to dried samples subjected to simulated gastrointestinal digestion ${ }^{(1)}$. The technique was modified to study foods and meals as eaten using ferritin as a surrogate marker of Fe availability. Two separate methods were used to study the effects of an Fe absorption enhancer and inhibitor on ferritin formation in Caco-2 cells. Ferritin is the main storage protein for Fe, and specifically Fe ${ }^{3+}$ in enterocytes, and is well established as a surrogate marker of cellular Fe status ${ }^{(1,2)}$. Ascorbic acid, an Fe absorption enhancer ${ }^{(3)}$, present in orange juice or an ascorbic acid-rich salad, was subjected to an in vitro simulated digestion ${ }^{(1)}$ in conjunction with cooked egg, a rich source of poorly-available $\mathrm{Fe}^{(4,5)}$. The digestate was applied to Caco-2 cells (using a dialysis membrane to protect the cells from digestive enzymes and food particles) for $2 \mathrm{~h}$ and ferritin formation was measured after $24 \mathrm{~h}$. The effect of orange juice and also of freeze-thawing of the digestate before adding to the cell model (to facilitate timing of the experimental work) on the solubility of Fe was also studied. Ca, an $\mathrm{Fe}$ absorption inhibitor ${ }^{(6)}$, was added to the cell culture media in the presence and absence of Fe and ferritin formation measured. The presence of ascorbic acid in the digestate following in vitro digestion increased the formation of ferritin in the Caco- 2 cells as well as the concentration of soluble $\mathrm{Fe}$ in the digestate. Freezing the digestate also caused an increase, possibly as a result of rupture of cell walls increasing release of $\mathrm{Fe}$ into solution. In contrast to this finding, supplementation of the cell culture media with Ca suppressed the formation of ferritin, indicating a reduction in Fe transport into the cell. These results agree with published in vivo data and support the use of Caco-2 cells as a model of the epithelium of the small intestine and also the use of ferritin as a surrogate marker of Fe availability. Furthermore, the results show that digesting an ascorbic acid-rich food in conjunction with egg will increase Fe availability.

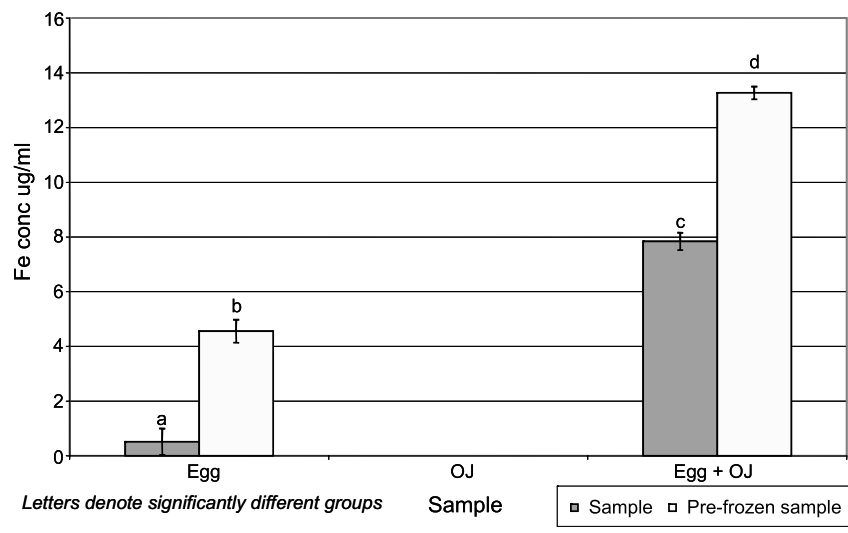

Fig. 1. Effects of freezing on soluble iron concentration in digestate $(\mathrm{n}=3,+/-\mathrm{SD})$.

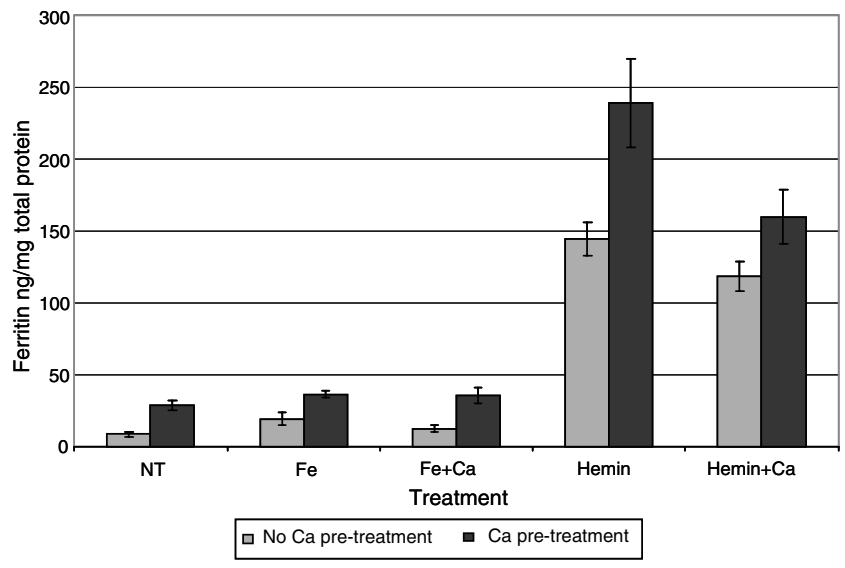

Fig. 3. Ferritin formation in cells treated with iron $+/-$ calcium following a calcium pre-treatment $(n=6,+/-S D)$.

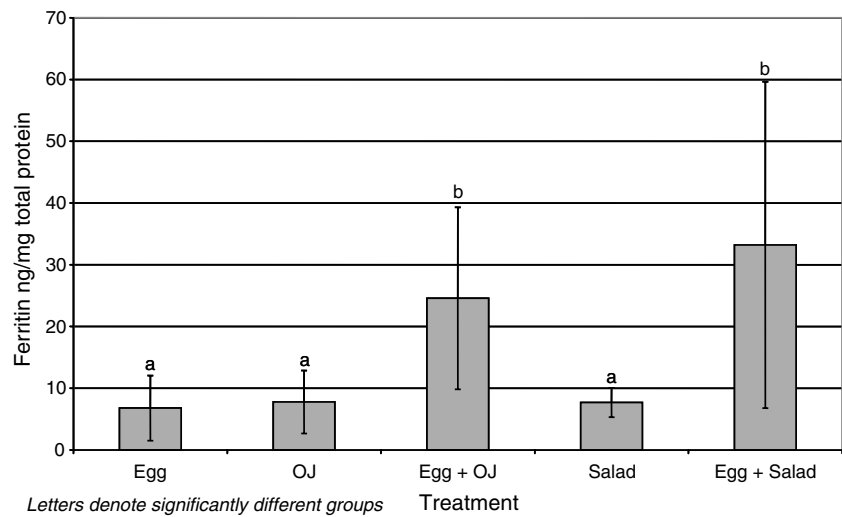

Fig. 2. Ferritin formation in cells treated with digested samples $(n=9,+/-\mathrm{SD})$.

1. Glahn RP, Lee OA, Yeung A et al. (1998) J Nutr 128, 1555-1561.

2. Aisen P, Enns C \& Wessling-Resnick M (2001) Int J Biochem Cell Biol 33, 940-959.

3. Lynch SR \& Stoltzfus RJ (2003) J Nutr 133, 2978S-2984S

4. Callender ST, Marney SR Jr \& Warner GT (1970) Br J Haematol 19, 657-665.

5. Ishikawa SI, Tamaki S, Arihara K et al. (2007) J Food Sci 72, S412S419.

6. Kletzien SW (1940) J Nutr 19, 187-197. 